\title{
Can the Reason for Sexual Abuse of Children Be Inadequacy in Sexual Education?
}

\author{
İsmail Çelik \\ Department of Educational Science, Faculty of Education, Ağrı İbrahim Çeçen University, Turkey
}

Copyright $(2018$ by authors, all rights reserved. Authors agree that this article remains permanently open access under the terms of the Creative Commons Attribution License 4.0 International License

\begin{abstract}
The human being who is accepted as a good being in need of creation is the result of the interaction that he has established with his surroundings. He is ignorant when he is considered not to be equipped with the necessary information for himself when he is born and is making efforts to obtain this information. Firstly, these informants, which parents should make, try to go with the environment where they feel closer to them if the information of the parents is not sufficient. At this point abuse is on the agenda. Malicious people sail into a number of exploits under the image of helping children, especially by using their curiosity. For this reason, the aim of the research is to try to prevent sexual exploitation by ensuring that the needs of the children who want to have information on various subjects are saturated by the parents with the sexual education program. Through a sexual education program provided by parents or competent authorities, children will be better able to recognize themselves and to be careful of all the dangers they may have from their surroundings. The issue of sexual abuse presents cultural differences, especially in the eastern and western part of our country, in different forms. For this reason, the research was carried out in Ağrı province, which is in a different position due to its cultural structure. In the study, case study design was used. 97 people, 75 female and 22 male, who were reached by random sampling, were interviewed and the data obtained was analyzed by content analysis method and presented in tabular form. In the study, the thoughts are tried to be revealed on how children who were abused perceive this issue, why they hide and on educating children on sexual abuse to overcome this problem. When the findings were examined, it was seen that $91 \%$ of participants think that it would be appropriate to educate pre-school children about sexual information in order to protect them from sexual abuse. The percentage of those who advocate for teachers to be informed about child abuse is $97 \%$. It is stated that the reasons for hiding the abuse are embarrassment, $61 \%$, and fear, 39\%. For the question, by whom children are abused, $61 \%$ of the respondents give a thought-provoking answer which is close environment. Because interviews with selected people after the first interview indicated that the interaction of the close environment with children is seen as normal. Our research
\end{abstract}

and investigations done related to the topic show that abuse and particularly sexual abuse is experienced intensively in our country. In our research, it was determined that teachers, students and especially parents, have incomplete information about sexual education. For this reason, cooperation within the Ministry of National Education and Higher Education Institution should be ensured that the schools are equipped with sexual education programs that will enable teachers, students and parents to be more effective in sexual abuse.

Keywords Sexual Abuse, Children, Parent, Sexual Education, Program

\section{Introduction}

Sexuality, which is necessary for the continuation of human life, is accepted as the basic necessity which has emerged with the existence of man and will continue until death. The ability to live this in sufficient maturity is closely related to the level of knowledge that people living together in society have. Mankind is coming to the world in a defenseless way and trying to maintain their life with what they learn. As is the case in all matters, the situation is the same at the point of basic needs. In Maslow's theory of needs, the sexuality found at the most basic level of physical or physiological needs is regarded as a prerequisite for the individual to realize himself in the next stages [1]. While these needs normally need to be addressed within the boundaries set out in the law, the times when they are outside these boundaries are also quite many. Although sexuality shows itself at every age, it is known that sexual needs and demands are fully formed in the adolescence period and called sexual maturity [2]. The institution called marriage is regarded as an institution with important functions at the point of meeting these needs on a regular basis. When it comes to religion, marriage is seen as a sacred event and considered important for the future of society [2]. The experience of sexuality outside of marriage gives harm to the individuals and the society, and in some cases, especially it takes a perverted status and turns to the children. The main reason for this can be seen as that 
people, especially parents, do not have enough knowledge on this issue.

Abuse is defined as exploitation of one's goodwill in the TDK dictionary [3]. The concept of goodwill is seen as a concept that overlaps them when considered from the point of view of children, which means that the most abused ones are children. Types of abuse were taken in 3 groups by the World Health Organization. These are Physical Abuse, Emotional Abuse and Sexual abuse [4]. Physical abuse is a kind of abuse that is as it is used in the proverbs of "don't spare the rod ", "spare the rod and spoil the child", "the beating is out of heaven" for the discipline of the child [5]. Another type of abuse is defined as an abuse that prevents individuals from being psychologically developed by depriving them of interest and love [6]. Sexual abuse, on the other hand, is a type of exploitation, which is most often victimized by children who are engaged in related needs. In fact, sexual abuse is a condition in which children who are victims of other forms of abuse are living in abundance. Because children who are exposed to physical and emotional abuse are looking for love and compassion that they see as need in places other than their parents, so they become victims of malicious people who are waiting for ambush.

Ağr1 is seen as one of the provinces which are educationally backward. When the literacy rate in Turkey is taken into consideration, Sırnak and A $\breve{g r} 1$ have the lowest rate of literacy with $89.3 \%$ [27]. Ağrı province is also one of the provinces with the lowest ranking in terms of socio-economic status. In the study which is done by SERKA shows that for the complete development of Ağrı, a large-scale investment is needed [28]. Ağrı province is seen as a backward province both in literacy rate and socio-economic status, so it is open to sexual exploitation.

The aim of the research is to try to prevent sexual exploitation by ensuring that these needs of children who want to have knowledge in various subjects are fulfilled by the parents with the sexual education program. Through a sexual education program provided by parents or competent authorities, children will be better able to recognize themselves and to be careful of all the hazards they may have from their surroundings. The data presented within the scope of the research are important in terms of ensuring prevention of situations that may become a social problem in the future by advocating the necessity of sexual education at the point of protecting children against sexual abuse.

\subsection{Researches on the Topic}

When the literature on child abuse and sexual education is examined, it has been observed that studies and reports on child abuse are sometimes presented, but studies on sexual education are inadequate. Nevertheless, there were no studies on the relationship between these two concepts. It is suggested that it is necessary to subject the parents, the teachers and children to a sexual education program in order to ensure that pre-school children are protected from sexual abuse.

Many researches have been done on child abuse in our country in recent years, especially in medicine. $[7,8,9,10$, $11,12,13,26]$. In the study conducted by Taner \& Gökler from these studies, it was determined that the children who were sexually exploited had malfunctioning families. It was emphasized that these families had either repressive families or sexual problems in the family. In the study conducted by Pelendecioğlu and Bulut (2009) [14], it is mentioned that abuse applied within the family is considered as a cultural norm and this practice made by the children's closest people has harmed the personality of the child and it has been emphasized that the legal regulations in this area should be observed. In the study conducted by Üstündağ et al. (2015) [15], it was stated that parental knowledge levels related to child abuse were determined and interviewed at different times to raise their awareness level. Oktay's work in 2001 revealed that teachers' professional lives were exposed to various forms of sexual exploitation by managers, teachers, students and other employees [16]. It is observed that the problems related to the subject are experienced due to the inadequacies in sexual education.

When studies on sexual education are examined, it is seen that not only children but also married people have inadequate information on these issues [23, 17, 18]. It is also known that studies on sexual education have more work in health dimension than education dimension. Both sexual abuse and sexual education are multidimensional, so an interdisciplinary approach should be considered [25].

In relation to information about sexual education, the child's interest from the age of 3 and subsequent questions should be answered satisfactorily by the parents in time [23]. It is possible that these answers can be given by the level of knowledge possessed by the mother and father in sexual matters. For this reason, it is necessary for parents to take sexual education as a part of the child's development and to receive the necessary education in order to support this development [19]. Because sexual abuse is likely to happen when sexual education cannot be done properly.

\section{Method and Data Collection Tools}

In the study, case study design was used. 97 people, 75 female and 22 male, who were reached by random sampling, were interviewed and the data obtained was analyzed by content analysis method and presented in tabular form. In the study, the thoughts are tried to be revealed on how children who were abused perceive this issue, why they hide and on educating children on sexual abuse to overcome this problem.

All the neighborhoods in Ağrı province which is located in the eastern part of Turkey are taken into consideration while determining the sampling. In the process of determining the sample, questions on whether children had 
faced with sexual exploitation are not asked, only the views are asked about the sexual exploitations in the close environment of the attendants. The reason why such a question is not asked is because of the possibility that the participants who are already abstaining from the interview are not willing to discuss it. Although the information about the selected neighborhoods in the study has been officially disclosed, it shows the existence of sexual abuse.

As a data collection tool, a structured interview form with personal information form was used and the following questions were asked:

- By whom are children abused mostly?

- Why do not the children tell when they are exposed to abuse?

- Should teachers be trained in child abuse and sexual education?

- Does the pre-school child need to be informed about abuse and sexual education?

The answers given to these questions were interpreted with the content analysis technique and turned into tablatures and compared with the other study data.

\section{Findings and Discussion}

The study was carried out on 97 parents living in the province of Ağr and the information on the distribution of the participants is given in the graphic below.

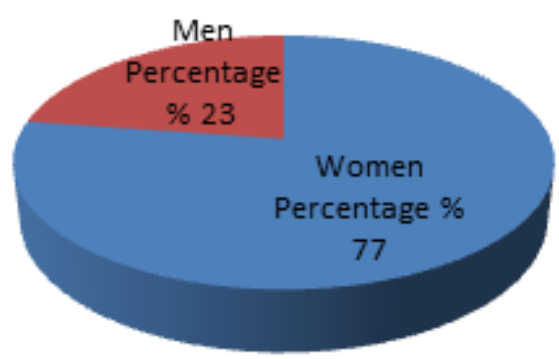

Graph 1. Distribution of the participants according to gender

A total of 97 people, 22 males and 75 females residing in the province of Ağrl, have participated in the survey.

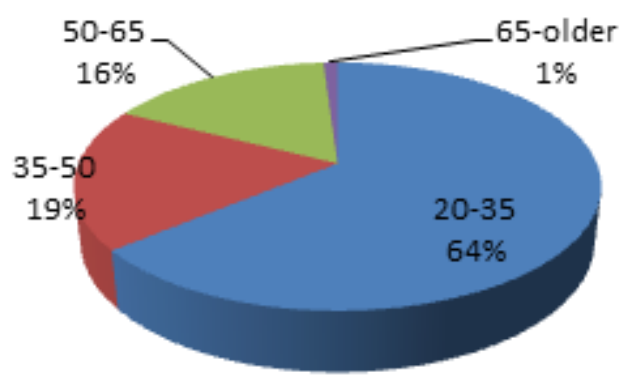

Graph 2. Distribution of the participants according to age

While younger parents make up $64 \%$ of the participants in the survey, $19 \%$ of them are between $35-50$ years old and $17 \%$ of them are 50 years old and upwards.

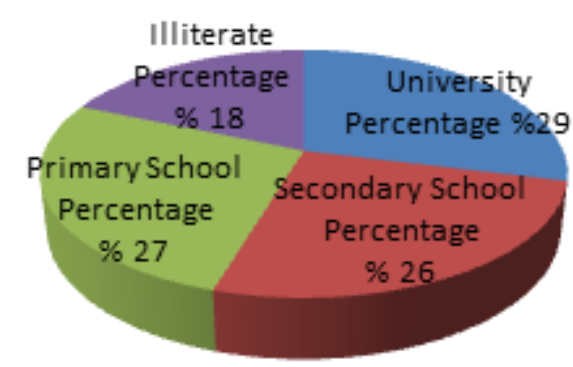

Graph 3. Distribution of the participants according to education level

Parents participating in the research also have different educational background. It seems that there is almost the same participant in each level. This suggests that the level of education can be dismissed in terms of generalization of the obtained data.

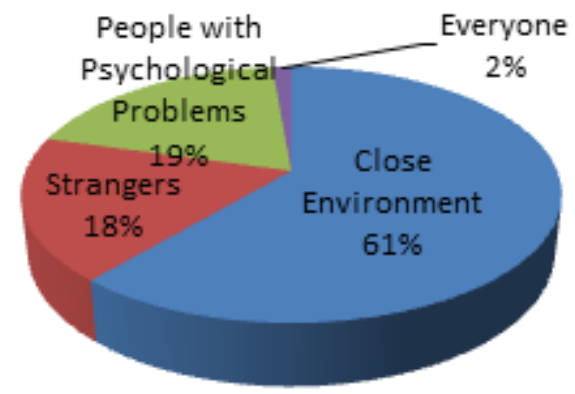

Graph 4. By whom are children abused mostly?

It is accepted as a thoughtful result that $61 \%$ of the people who are involved in the investigation are more familiar with the environment. Again, even if it is $2 \%$, the answer in which they tell that everyone may abuse should be seen as an answer that should be taken into consideration. The responses of the participants are in fact contrary to the attitudes of the local people on children's issues. This is because families who have a structure that overlooks tolerance and who do not have any doubts about communication and interaction with children express that abuse is seen in close environment, can be interpreted as knowing the problem and acting insensitive to it.

Negative rhetoric about the gender of the children in terms of the sexual dimension and the religious dimension revealed that the children are educated with the wrong discourse about sexual education and personality development is adversely affected [20]. In fact, it is seen that the answers given by the parents reveal their own responsibilities.

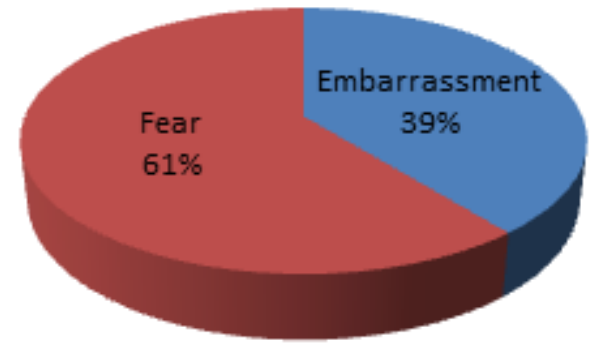

Graph 5. Why do not the children tell when they are exposed to abuse? 
It was seen in the question asked to explain why children do not tell the abuse, $61 \%$ of the responses see the issue due to fear and $39 \%$ due to embarrassment. This is due to the fact that children do not have enough knowledge about sexual education and that they see sexual education as a taboo as a topic that should not be discussed at all. What to do; is to ensure that parents are adequately informed about sexual education and sexual abuse in the most effective manner.

According to Valles, there are three qualities of human sexual life: biological, social and spiritual. Biological quality is the transfer of life, social quality is helping the child to develop personality in a safe manner, and what belongs to the spiritual is the transgression of gender instinct to love. Both parents and the teachers should be informed that this information is required to be clearly stated and should not be lied to the children. Because when it comes to sexual issues, children's problems are reduced as they are told normally [21].

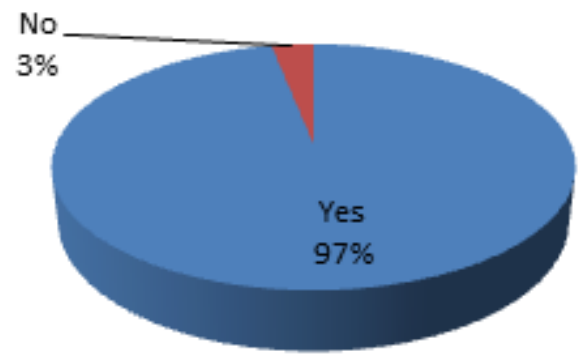

Graph 6. Should teachers be trained in child abuse and sexual education?

Almost all the participants give supportive answer to the question "Should teachers be trained in child abuse and sexual education?". Indeed, there is such a gap in sexuality that even teachers do not have enough knowledge in this regard because they have not taken any lessons in these subjects during their undergraduate education. For this reason, they do not have enough knowledge to teach about sexuality. It is necessary to educate the lecturers in this regard first, then to educate the parents and lastly to inform children with the cooperation of parents and teachers.

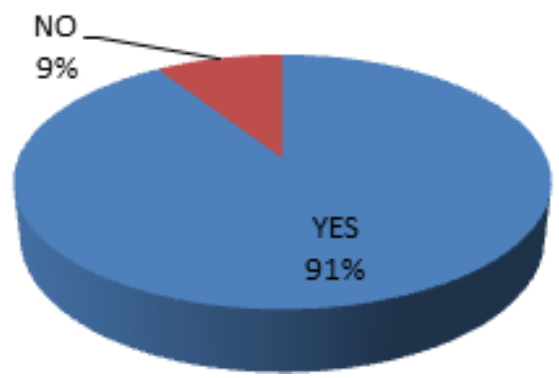

Graph 7. Does the pre-school child need to be informed about abuse and sexual education?

It was emphasized that it is possible to prevent children from sexual abuse with the answer given $91 \%$ of the respondents to the question about giving sexual abuse and sexual information to pre-school children. However, who should give this information? Of course the answer to this question will be parents. But parents have to be trained in information transfer. Because, sometimes, parents can be very angry with no reason and sometimes tolerant when they communicate with their children [21]. It is essential for parents to be trained in this regard.

In fact, the answers given by parents to children's questions about sexual education can be taken as a sexual education. But the thing to note here is that this education must be on the value of reality. In fact, there is a lot of misinformation that is rooted in the problems of sexuality [22].

\section{Conclusions and Evaluation}

When the findings obtained from the research are examined, it is revealed that there is an effect of the events occurring within the family at the point of exploitation of the children. It has been observed that children have difficulties because they cannot get the necessary information from their parents about sexual abuse and they cannot realize the abuse they face because they do not have sufficient knowledge about sexual education and they cannot give them the necessary response. Trainees also help parents and children in this regard. We can see how vital it is if teachers' role in rural areas is taken into account. Another assistant with the teachers is accepted as imams in the villages. These people, who can be described as wise, can inform the public that they are inadequate. But unfortunately these people are in a position to be insufficient in sexual education. Walker tells about the situation of clergy (Christian clergy!): "In sexual matters, they have not been seen as more ignorant than their clergy" [24] It is therefore essential that both teachers and religious leaders are trained in these matters.

The inadequacies of sexual education are a fact revealed by our research and other researches. In our study, it was found that the lack of knowledge of the parties on sexual education was a serious factor in sexual exploitation. A cross-disciplinary study should be carried out to determine the situation in the whole country and to prepare an effective sexual education program by taking the contributions of the related parties in this issue. The issue of sexual exploitation necessitates the co-ordination of family, school and other institutions. At this point, the findings, necessary precautions and education should be exercised together with the related departments of the universities and the provincial directorate of national education. The issue should be handled in every province with a wide perspective with annual plans. More happy and conscious generations can be trained by providing information to the people of our country about the whole sexual education through the works to be carried out in cooperation with the Ministry of Health, Higher Education Institution, Ministry of National. 


\section{REFERENCES}

[1] Maslow, A. H. A Theory of Human Motivation. Psychological Review 50, 370-396, 1943.

[2] Feyerabend, W. Cinsiyet Alfabesi, Çev.(C.C. Cem), İstanbul: Remzi Kitabevi. 1954.

[3] "İstismar." is taken from the website of Türk Dil Kurumu Büyük Türkçe Sözlük. www.tdk.gov.tr on 29.03.2017.

[4] World Health Organization. The world health report: working together for health, 2006.

[5] Unicef. Study on Child Abuse and Domestic Violence in Turkey, 2010.

[6] Polat, O. Child and violence. Istanbul: Der Publishing. 2001.

[7] Taner, Y., \& Gökler, B. Çocuk istismar ve ihmali: psikiyatrik yönleri. Hacettepe Tıp Dergisi, 35, 82-86, 2004

[8] Bulut, S. Çocuk Cinsel İstismarı Hakkında Bir Derleme, Türk Psikolojik Danışma Ve Rehberlik Dergisi, III (28), 139-156, 2007.

[9] Ovayolu, N., Uçan, Ö., \& Serindağ, S. Çocuklarda cinsel istismar ve etkileri. Firat Sağllk Hizmetleri Dergisi, 2(4), 13-22, 2007.

[10] Tıraşçı, Y., \& Gören, S. Çocuk istismarı ve ihmali. Dicle Tip Dergisi, 34(1), 70-74, 2007.

[11] Ceylan, A., Tuncer, O., Melek, M., Akgün, C., Gülmehmet, F., \& Erden, Ö., Van bölgesindeki çocuklarda cinsel istismar. Van Tip Dergisi, 16(4), 131-134, 2009.

[12] Bilginer, Ç., Hesapçioglu, S. T., \& Kandil, S. Çocukluk Çağı Cinsel İstismarı: Mağdur ve Sanık Açısından Çok Yönlü Bakış. Düşünen Adam, 26(1), 55, 2013.

[13] Özer, E., Tokdemir, M. B., Yıldırım, A., Koçak, U., Bütün, C., \& Enginyurt, Ö. Mitolojide çocuk istismarı olguları. Cumhuriyet Medical Journal, 36(1), 111-115, 2014.

[14] Pelendecioğlu, B., \& Bulut, S. Çocuğa yönelik aile içi fiziksel istismar. Abant İzet Baysal Üniversitesi Ĕ̌itim Fakültesi Dergisi. 9(1), 49-62, 2009.

[15] Üstündağ, A., Şenol, F. B., Mağden, D. Ebeveynler Çocuk İstismarına Yönelik Bilgi Düzeylerinin Belirlenmesi ve Bilinçlendirilmesi. Hacettepe University Faculty of Health Sciences Journal, 1, 212-227, 2015.

[16] Oktay, A.. İşyerinde Cinsel Taciz ve İstismar, Kadın Araştırmaları Dergisi, 7, 75-89, 2001.

[17] Set, T., Dağdeviren, N., \& Aktürk, Z. Ergenlerde cinsellik. Genel Tip Dergisi, 16(3), 137-141, 2006.

[18] Kısa, S., Zeyneloğlu, S., Yılmaz, D., \& Verim, E. Evlilik Hazırlığı Yapan Çiftlerin Cinsellikle İlgili Bilgi ve İnanışları. TAF Preventive Medicine Bulletin, 12(3), 297-306, 2013.

[19] Çalışır, D. Cinsel Ĕgitim \& Çocukluktan Ergenliğe, İstanbul: Profil, 2011.

[20] Özgün, H. Cinsiyet Eğitimi, İstanbul: M. Ali Basımevi, 1955.

[21] Valles, A., Ana Babaların Eğitimi, (Çev., Mehmet Toprak), İstanbul: Remzi Kitabevi, 1963.

[22] Berge, A. Çocuğun Cinsel Eğitimi, (Çev., Nazife Müren), İstanbul: Remzi Kitabevi, 1969.

[23] Bulut, A. Çocuklukta Cinsel Eğitim, Türk Aile Hekimleri Dergisi, 2 (2), 53-57, 1998.

[24] Walker, K., Fizyoloji Açısından Cinsiyet, (Çev., Ender Gürol), İstanbul: Varlık Yayınevi, 1964.

[25] Bakır, E., \& Kapucu, S. Çocuk İhmali ve İstismarının Türkiye'de Yapılan Araştırmalara Yansıması: Bir Literatür İncelemesi. Journal of Hacettepe University Faculty of Nursing, 4(2). 13-24, 2017.

[26] Teyfur, Mehmet, Et Al. "Eğitim Fakültesi Öğrencilerin Akademik Erteleme Davranişlari İle Sosyal Medya Bağimliliği Arasindaki İlişkinin Farkli Değişkenler Açisindan İncelenmesi." Electronic Turkish Studies 12.33 (2017).

[27] Kaya, Faruk. Literacy Situation Analysis of Agri Population between 1928 and 2015, The Journal of Academic Social Science Studies, 52, 29-47.

[28] Serka. Ağri'nin Sosyo-Ekonomik Durumu Ve Uygun Yatirim Alanlari, T.C. Serhat Kalkinma Ajansi Ağri Yatirim Destek Ofisi, 2013. 